\title{
OS EFEITOS DA ICONICIDADE NA PRÉ-ALFABETIZAÇÃO: UM ESTUDO PSICOLINGUÍSTICO DE PAREAMENTO FIGURA- PALAVRA ESCRITA
}

\author{
Isadora Rodrigues de Andrade ${ }^{1^{*}}$ \\ Ana Luiza H. Tinoco Machado ${ }^{1 * *}$ \\ Aniela Improta França ${ }^{1^{* * *}}$ \\ ${ }^{1}$ Universidade Federal do Rio de Janeiro, Rio de Janeiro, RJ, Brasil
}

\section{Resumo}

Este trabalho tem como objetivo investigar, a partir da perspectiva da linguística experimental, o uso da iconicidade como estratégia de leitura provisória utilizada pelas crianças, durante a fase de pré-alfabetização. Contrastamos o recrutamento de iconicidade com a noção de arbitra-riedade linguística default, como proposta por Saussure. Para testar a interação dessas duas apostas cognitivas - iconicidade e arbitrariedade - em crianças de três faixas etárias, 4,5 e 6 , propomos um experimento do tipo role-playing a fim de verificar se esses participantes usam relações icônicas para guiá-los em uma tarefa de pareamento entre figura e palavra escrita. Nossos resultados mostram que a iconicidade é um recurso usado por algumas crianças, especialmente as menores, de 4 anos, que tendem a estabelecer uma relação motivacional mais clara entre o tamanho dos objetos e o tamanho da palavra que os nomeia. Verificou-se que a iconicidade ainda persiste como estratégia de leitura em algumas crianças de 6 anos de idade, quando estão na idade de se engajarem em um programa formal de alfabetização. Diante desses resultados discutimos as implicações da escolha do método de alfabetização, seja favorecendo a leitura global ou a decodificação grafema-fonema, em relação, principalmente, a essas crianças, que tendem a preservar a estratégia icônica por mais tempo.

Palavras-chave: Arbitrariedade do Signo; Iconicidade; Aquisição da Leitura; Métodos de Alfabetização

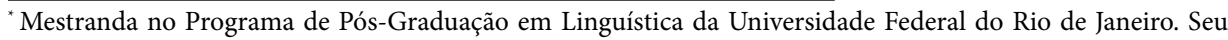
e-mail é: andradeisadorar@gmail.com. ORCID: https://orcid.org/0000-0002-5822-3501.

${ }^{*}$ Doutoranda no Programa de Pós-Graduação em Linguística da Universidade Federal do Rio de Janeiro. Seu e-mail é: analuiza_tinoco@hotmail.com. ORCID: https://orcid.org/0000-0002-0427-643X

${ }^{* * *}$ Dra. em Linguística (Universidade Federal do Rio de Janeiro). Professora Associada do Departamento de Linguística na Universidade Federal do Rio de Janeiro. Bolsista de produtividade em pesquisa do CNPq. Bolsista do Programa Cientista do Nosso Estado (FAPERJ). Membro fundador da Rede Nacional Ciência para Educação. Seu e-mail é: aniela@gmail.com. ORCID https://orcid.org/0000-0002-3614-2970
} 


\section{THE EFFECTS OF ICONICITY ON PRE-LITERACY: A PSYCHOLINGUISTIC STUDY OF WRITTEN WORD-FIGURE MATCHING}

Abstract

This article aims at investigating, from the perspective of experimental linguistics, the use of iconicity as a provisional reading strategy used by children during the pre-literacy phase. In the background, we contrast the recruitment of iconicity with the notion of default arbitrariness in language, as proposed by Saussure. To test the interplay of these cognitions, we propose a role-playing experiment with children from three age groups, 4,5 and 6 , in order to verify if these participants use iconic relations to guide them in a task of pairing figure to written word. Our results show that iconicity is a first-hand resource used by some children, specially 4 year-olds, who tended to establish a clearer motivational relationship between the size of objects and the size of the word that names them. Nevertheless, iconicity persists as a strategy in a few 6 year-olds, on the brink of attending literacy class. Considering these results, we discuss the implications of choosing a literacy method, either favoring global reading or grapheme-phoneme decoding, specially for the kids who tend to preserve the iconic strategy longer.

Key-words: Arbitrariness; Iconicity; Reading Acquisition; Literacy Methods 


\section{Introdução}

Ao observar crianças se desenvolvendo, temos fartas e fascinantes evidências de que, a todo tempo, elas criam hipóteses sobre o funcionamento das mais diversas coisas do mundo a sua volta. A partir da infância, está em processo a pujante formação de uma arquitetura cerebral complexíssima, dotada de modelos conceptuais de como organizar e entender tudo aquilo que é possível captar, levando em conta as restrições impostas pela genética da nossa espécie. O campo de estudos que busca entender como as pessoas vão representando no cérebro o mundo que percebem desde o nascimento, como elas identificam padrões, sistemas classificatório se deslancham ferramentas para resolver os problemas que elas conceptualizam, vem se especializando há pelo menos 2000 anos, e chega aos nossos dias com o nome de Ciências Cognitivas (CARRUTHERS, LAURENCE, STITCH, 2005; FETZER, 1992; LANGACKER, 1987).

No centro das Ciências Cognitivas há alguns assuntos cruciais que dividem os pesquisadores, e entre eles está o debate nature e nurture: somos o resultado de nossa genética, que atua moldando o que somos de dentro para fora, ou somos determinados de fora para dentro, pela nossa experiência sociocultural? Mais e mais a combinação dinâmica dessas forças antagônicas parece ser a resposta para a pergunta. De um lado, a habilidade de organizar modelos e padrões para entender o mundo parece ser franqueada pelo código genético da espécie (ANDERSON, 1983; CHURCHLAND, 1989; FODOR, 1983), enquanto a interpretação dos padrões parece estar mais ligada à cultura (LAKOFF,1987; LAKOFF and JOHNSON, 1980; LAKOFF and TURNER, 1989). Não se pode excluir uma da outra. Por exemplo:

Todos os humanos têm uma capacidade inata de conceptualizar cada coisa como tendo frente e costas. No entanto, na cultura ocidental, nossa noção do que constitui, digamos, a frente de uma casa pode variar em relação a que outra cultura pode perceber. Assim, a aplicação do modelo "frente / costas" varia entre as culturas, mas o significado subjacente permanece idêntico. DAVIS et al, 2011:11

Cabe, aqui, uma ressalva a Gardner (2011). Já que é claro que o modelo frente/costas difere mais entre itens quando se trata de casas e livros e muito menos quando se trata de pessoas ou animais, as características que definem a frente de uma pessoa ou de um animal de suas costas não diferem entre as culturas; ou seja, há variação entre tokens de um mesmo modelo cognitivo, mesmo quando ele é invariável. Podemos, então, vislumbrar a complexidade dos modelos cognitivos, modulados idiossincraticamente por uma dinâmica dificilmente apreensível entre genética e cultura.

Além disso, há ainda a perspectiva evolutiva em jogo. Se o modelo frente/ costas está mesmo codificado na genética da espécie, certamente o é porque essa noção tem significativa importância e foi selecionada para ser mantida no código. De fato, a vida pode depender de se saber reconhecer se, diante de si, estão as 
costas ou a frente de um predador do qual se quer fugir. Transpondo o contexto para um cenário urbano atual, também pode ser desejável saber se o chefe estava de frente ou de costas quando se decidiu descansar no meio do expediente. Então, essa codificação específica e valorosa do modelo frente/costas foi paulatinamente incorporada à espécie e vem sendo mantida e provavelmente refinada nos 180.000 anos que habitamos esse planeta.

Outros modelos cognitivos podem não estar codificados geneticamente e, portanto, podem não ser hoje espontâneos, porque são muito mais recentes. É o caso da escrita e leitura que até conseguimos automatizar mediante instrução, apesar de ter sido introduzida socialmente somente há 5.500 anos, ou seja, um tempo equivalente a $3 \%$ da vida do homem na terra ( $c f$. ANDRADE, FRANÇA, SAMPAIO 2018).

Para alguns estudiosos, nesses casos em que a pressão evolutiva não é profunda o suficiente para ser selecionada naturalmente na lenta evolução da espécie, a aquisição cognitiva pode se dar por reciclagem neuronal. A hipótese da reciclagem neuronal sustenta que neurônios podem passar por plasticidade detonada através de uma exposição cabal a um problema cognitivo por uma instância de instrução ostensiva, que organize os conteúdos, explicite os padrões do sistema e pratique as correspondências. A educação formal é um ótimo exemplo de situação cultural que poderia dar o pontapé inicial na reciclagem neuronal de alguma área cerebral.

É isso que acontece com a leitura. Essa nova aquisição cultural acaba cooptando um conjunto de circuitos neuronais que já exercia alguma função suficientemente próxima da função requerida pela nova tarefa, e que é suficientemente plástico para se reorientar parcialmente para o novo uso. À medida que os circuitos neurocorticais dedicados a funções evolutivas mais antigas, como aqueles que subservem à identificação de objetos, são invadidos por novos objetos culturais, como por exemplo a identificação de grafemas, sua organização prévia nunca é inteiramente apagada e continua a se manifestar influenciando a nova função cognitiva(cf. COHEN, DEHAENE, 2004; DEHAENE, COHEN 2007, 2011; DEHAENE et al 2010; DEHAENE, 2012).

No reconhecimento de objetos, grande parte dos neurônios do córtex temporal inferior apresenta uma resposta bem rápida a formas específicas de configurações visuais presentes no exterior de formas de três dimensões. Portanto, o reconhecimento de objetos se dá principalmente pela identificação desses pontos estratégicos de junção. São esses pontos de intercessão das linhas e seus ângulos que nos fazem reconhecer um cubo, por exemplo, na Figura 1. O mesmo processo acontece com o reconhecimento de grafemas, que também se caracterizam pelas junções e interceptações de linhas padronizadas. Notam-se, ressaltados pelos círculos vermelhos, os grafemas que contêm linhas e ângulos que nada mais são do que detalhes da figura geométrica do cubo apoiado em uma superfície plana (DEHAENE, 2012). 
Figura 1: Desenho em perspectiva de um cubo apoiado em uma superfície plana, ressaltando junções encontradas em objetos de três dimensões e em diferentes grafemas (Retirado de DEHAENE, 2012:156).

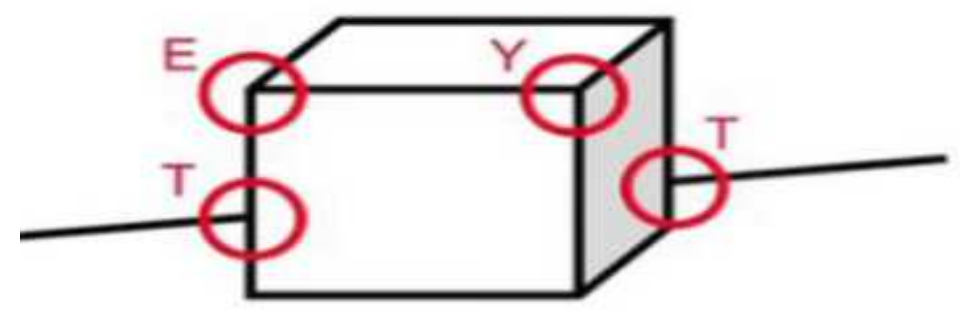

Nessa reciclagem que se estabelece durante a alfabetização, surge a Área Visual da Forma da Palavra (VWFA - Visual Word Form Area) que se avizinha da área do reconhecimento de objetos. Na verdade, a VWFA também recicla neurônios da área de reconhecimento de faces, que também se utiliza de padrões visuais estratégicos para ler as características faciais que nos permitem a identificação de pessoas (Cf. DEHAENE 2014 para uma revisão completa da neurofisiologia da leitura, incluindo as áreas recicladas).

Em resumo, a reciclagem neuronal para a leitura se dá a partir da exposição estruturada ao sistema da língua escrita por uma instância educacional, ao longo de um ou mais anos. As crianças tipicamente passam pela classe de alfabetização dos 5 aos 7 anos e lá obtém a exposição sistematizada da relação grafema-fonema que pode ensejar a reciclagem.

Contudo, antes disso, nos anos anteriores à alfabetização, há relatos de que algumas crianças já tentam sistematizar as convenções da escrita. Isso é compreensível já que elas já podem ter tido contato abundante com a escrita em muitas situações cotidianas. Ouvem os pais contando histórias a partir dos livros, veem placas, cartazes, pixações na rua, etc. Ou seja, pode haver motivação para que elas percebam na escrita um problema cognitivo a ser solucionado.

Com efeito, algumas crianças aos 2 e 3 anos já fingem estar lendo algum texto e demonstram terem assimilado vários padrões da leitura: (i) seguram o texto de cabeça para cima, (ii) sabem a diferença entre ilustração e texto, (iii) conhecem a orientação da leitura na sua língua, por exemplo, sabem que em português as palavras são lidas da esquerda para a direita, (iv) controlam o início e o fim da leitura, (v) e, com o dedo, seguem as palavras lidas, mesmo que errando nas correspondências (WU, HONIG 2013).

Para essas crianças, a escrita aparece primeiramente como um problema de representação. A um certo ponto elas se dão conta de que existe um sistema simbólico que se relaciona com o mundo imediato. A partir desse ponto, elas passam a criar suposições a respeito das regras que regem a leitura, regras essas que, posteriormente, podem ser confirmadas ou completamente descartadas (FERREIRO, TEBEROSKY 1991). 
Um fenômeno já bastante observado e relatado é a possibilidade de que a criança, nessa fase pré-alfabetização, antes de receber instrução explícita, use recursos cognitivos bem gerais para solucionar o problema do sistema de regras da escrita, lançando mão de um expediente de todo dia: a correspondência icônica. A relação de iconicidade estabelece que algum aspecto da forma ou tamanho do objeto se assemelha com algum aspecto da sua representação. Isso pode ser observado, por exemplo, nas crianças que frequentemente cantam músicas que combinam palavras com gestos representando objetos e ações ou informando aspectos do espaço ao redor.

No caso da escrita, as crianças podem supor, por exemplo, que deva existir uma correlação icônica entre o tamanho da coisa no mundo e o tamanho da palavra escrita que a representa: uma palavra pequena deve representar um objeto pequeno,assim como uma palavra grande deve representar um objeto grande. Consequentemente, elas podem supor que a palavra que grafa avião deveria ser muito grande porque avião é grande; da mesma forma poderia haver uma expectativa de que a palavra para formiga seja bem pequenina (FERREIRO, TEBEROSKY 1991; DINGEMANSE et al 2015).

Esse assunto nos coloca no centro de uma discussão fundamental para a Linguística: o nível de arbitrariedade e iconicidade existentes nas línguas humanas. As referências seminais sobre esse assunto vêm de dois suíços: pelo lado da arbitrariedade, a teoria estruturalista proposta por Ferdinand de Saussure (1916) que, certamente, constitui a base da chamada Linguística moderna; pelo lado da iconicidade, o realismo nominal relatado na epistemologia genética de Jean Piaget (1962).

Para Saussure, a ligação entre significante e significado é arbitrária; isto é, não há uma relação natural e necessária entre essas entidades (SAUSSURE, 1970). Em contraste, para a Epistemologia Genética de Piaget, o acúmulo de informações advindas da interação entre a criança e o mundo e entre a criança e outros sujeitos do mundo constroem estruturas mentais que são necessariamente icônicas e que, por isso, possibilitam a aquisição de procedimentos (HAIMAN 2008). Neste texto apresentaremos uma breve revisão dessas duas teorias.

Posteriormente, apresentaremos um experimento no estilo role-playing realizado com participantes na fase de pré-alfabetização. O seu objetivo específico foi verificar o nível de iconicidade recrutado por participantes não alfabetizados,de três faixas etárias, 4, 5 e 6 anos, ao estabelecerem uma hipótese para as relações entre palavras escritas e os objetos que elas representam.

Considerando os resultados obtidos, proporemos uma discussão sobre as metodologias de alfabetização, procurando identificar aquela que pode tornar o processo de alfabetização mais eficaz e menos custoso para as demandas cognitivas do aluno.

\section{Arbitrariedade ou Iconicidade?}

A tarefa de entendermos o que nos é falado envolve o pareamento fonológico do conteúdo lexical ao conteúdo semântico. Saussure pontuou com agudeza 
especial que na sequência fonológica que corresponde à garrafa, por exemplo, não há nada que nos dê uma pista ou uma indicação sobre o conteúdo semântico que o item representa. Em outras palavras, não parece existir uma correlação, similaridade ou motivação entre o sentido e a representação sonora do objeto.

Mas essa questão a respeito da ligação entre as coisas e os nomes que as representam vem sendo elaborada desde a antiguidade por filósofos como Platão, em seu célebre diálogo Cratilo ${ }^{1}$. No entanto, Saussure redireciona a discussão ao delimitar essa relação dentro do sistema linguístico. Ele propõe que a língua é um sistema, ou seja, um conjunto de unidades regidas por determinados princípios internos de funcionamento, gerando um todo coerente. A língua é entendida por Saussure como uma estrutura formada por unidades menores, signos linguísticos, formados por duas faces inseparáveis: significante e significado (SAUSSURE, 1916). O significante pode ser compreendido como a sequência sonora que forma uma palavra, enquanto que o significado é interpretado como o sentido conferido ao significante. Entretanto, não se deve compreender ambos os termos enquanto realidade física. Pelo contrário, significante e significado são entidades psíquicas independentes e mentais:

O signo linguístico une não uma coisa e uma palavra, mas um conceito e uma imagem acústica. Estaimagem acústica não é o som material, coisa puramente física, mas a impressão desse som, a representação que dele nos dá o testemunho de nossos sentidos; tal imagem é sensorial e, se chegarmos a chamá-la 'material', é somente nesse sentido, e por oposição a outro termo da associação, o conceito, mais geralmente abstrato. (SAUSSURE, 1916, p.80)

Ainda segundo Saussure, o vínculo que une significante ao significado é arbitrário. Isso significa que não há uma conexão essencial, obrigatória e natural entre o som e o sentido da palavra. O que existiria, então, é uma convenção estrita e implícita entre integrantes de uma dada comunidade linguística. Trata-se, portanto, de uma relação arbitrária. A arbitrariedade dessa relação entre forma e significado defendida por Saussure (1916) ficou conhecida como Arbitrariedade Saussuriana.

A arbitrariedade, então, se configura como um princípio específico do signo linguístico e, portanto, uma propriedade intrínseca a todas as línguas. De acordo com Saussure (1916), o princípio da arbitrariedade "domina toda a linguística das línguas" (p.82) e pode ser melhor percebido ao observar-se a diversidade que existe entre elas: um mesmo conceito pode ser representado por sequências sonoras distintas em diferentes idiomas.

Por exemplo, quando, na década de 40 , pensaram em um nome para o grande estádio de futebol do Rio de Janeiro, sua forma arredondada fez algum dos dirigentes que conhecia um pouco de tupi sugerir o nome maracanã, que significa forma semelhante a um chocalho naquela língua indígena. Dada a forma arquitetônica do estádio, foi, sem dúvida uma escolha icônica para quem cunhou o termo, e essa escolha vem sendo passada adiante sem ter de ser remetida ao tupi. Agora, se pudéssemos perguntar a todas as milhares de pessoas que enchem o 
Maracanã o porquê desse nome, veríamos que, provavelmente, poucos poderiam refazer a relação com um chocalho. Hoje aquela relação icônica entre forma e sentido tornou-se arbitrária.

Decorre dessas observações já consagradas, uma outra menos conhecida. É claro que, para que um termo consiga ser passado adiante sem que haja nenhuma motivação icônica que o naturalize, há de haver um sistema cognitivo nos falantes que acate passivamente a nomeação desmotivada. De fato, existe esse sistema e ele é muito forte especialmente nos primeiros anos de vida, quando sugamos os nomes que chegam até nós como uma forma de representarmos itens do mundo que vão ser usados nos pensamentos. Os bebês frequentemente têm os dedinhos em riste apontando para coisas e perguntando "Que é isso?", querendo que a mãe diga o nome de tudo. Assim, nota-se que, quando dizemos o nome de alguma coisa para uma criança e até para um adulto, quase como via de regra, não encontramos relutância do interlocutor em aceitar esse nome. Acata-se o nome e absorve-se a correspondência com a semântica. Saber o nome das coisas significa conseguir nomeá-las e pensar sobre elas. É um poder psíquico e isso é desejável.

Ao mesmo tempo que existe a arbitrariedade saussureana do signo linguístico evidenciada nos exemplos citados, há também instâncias claras de computações icônicas que fazem parte efetiva do raciocínio geral. Por exemplo, pode-se ver a iconicidade em funcionamento no chamado Efeito Bouba/Kiki. Wolfgang Köhler (1929) da Psicologia Gestalt, e posteriormente, Ramachandran e Hubbard (2001), da neurociência, estudaram esse efeito na correspondência entre o objeto e a palavra que o designa. Os últimos implementaram um teste de iconicidade que consistia em apresentar dois objetos inventados, um de forma arredondada e outro de forma pontiaguda, a participantes que tinham que escolher um entre dois nomes para nomear aqueles novos objetos. Cada participante deveria escolher atribuir aos objetos os nomes Bouba ou Kiki, conforme a sua vontade. Os resultados desse estudo apontaram que cerca de $98 \%$ dos participantes atribuíram à forma arredondada o nome Bouba e à forma pontiaguda, Kiki. Os experimentadores interpretaram que esse resultado expressava a iconicidade na linguagem, já que havia semelhança da forma do gesto articulatório, alongado para Kiki e arredondado para Bouba, interagindo respectivamente com a forma pontiaguda de um dos objetos e a forma arredondada do outro.

Ramachandran e Hubbard (2001) defenderam, assim, a ideia de que o processo de nomeação dos objetos não é arbitrário, mas, sim, motivado por características visuais da própria coisa. O efeito foi descrito como sinestésico, ou seja, que combina dois ou mais sentidos, no caso, visual e articulatório/auditivo.

Não podemos aqui deixar de apontar o fato de que havia um viés experimental nesse teste. Propunha-se que os participantes nomeassem as formas desconhecidas. Como já se discutiu acima, o ato da nomeação, criar um nome ou atribuir um nome a alguma coisa, suscita irremediavelmente o recrutamento da iconicidade. Se por outro lado, ensinássemos para os participantes que a forma pontiaguda tinha o nome de bouba e a arredondada de kiki, haveria acatamento completo desses nomes, assim como acatamos que espada é o nome 
da arma pesada e pontiaguda e espuma é o nome das bolhas leves, flutuantes e arredondadas de sabão.

Mas esse assunto ainda tem muitas outras dimensões. Sob o aspecto do desenvolvimento cognitivo, o psicólogo suíço, Jean Piaget (1962), descreveu um outro tipo de correspondência icônica típica da fase pré-alfabetização, que ficou conhecido como Realismo Nominal. Nesses casos, a iconicidade se manifesta especificamente por meio de uma relação de similaridade e motivação entre um aspecto da palavra escrita e uma característica da coisa representada: o tamanho.

Crianças nessa fase tendem a conceber a palavra como parte integrante do objeto a que se refere. Piaget denomina esta fase como Realismo Nominal e conta suas características como uma manifestação da iconicidade na cognição. A criança acredita que do próprio nome emanam as principais características do objeto. Uma instância ilustrativa desse fenômeno foi prestada em 2014 pela Professora Silvia Foschiera da UNISINOS e sua equipe. Elas fizeram curtas entrevistas informais ${ }^{2}$ com crianças e disponibilizaram na Internet. Nessas entrevistas, elas perguntavam coisas como "Por que carro se chama carro?". Como resposta, obtiveram: "Porque o carro tem portas e janelas"; "Porque a gente dirige ele" ou "Porque ele tem pneus".

Piaget explica esse fenômeno como se as crianças construíssem estruturas mentais necessariamente icônicas que se manifestam especificamente por meio de uma relação de similaridade com o rótulo. Sendo assim, o princípio da iconicidade, manifesto na linguística, estabeleceria uma correlação motivada e natural entre a forma e seu significado.

De fato, as ideias de Piaget e de outros teóricos vão influenciar em uma importante vertente linguística que surge na década de 1980: o funcionalismo. A ideia predominante nessa vertente é a de que a estrutura linguística representa, de alguma maneira, a estrutura da experiência (CROFT 2003, p. 102). Perniss et al (2010:2) descrevem algumas esferas em que é possível mapearmos iconicidade. De fato, estudos demonstraram que a iconicidade pode ser percebida nas línguas tanto no nível lexical, quanto no nível estrutural (GIVÓN, 1985; BERLIN, 1994) nas modalidades escrita, oral e gestual (PERNISS, 2010).

Para citarmos um exemplo concreto, Newmeyer (1992) argumenta que há ligações icônicas recorrentes nas palavras dos mais variados idiomas, como a iconicidade presente nas onomatopéias, imitação de sons que animais ou coisas fazem, como miau e crack como sendo um resultado da generalização acústica desse princípio. Assim, crack, usado como uma forma específica de quebrar ou como o barulho de algo quebrando, denotaria seu conteúdo através do contato forte entre os pontos de articulação no aparelho fonador que a sequência dos fonemas /k/;/r/; /a/ e /k/ provoca.

Uma outra variante desse processo foi chamada de Iconicidade Gestaltica (BUHLER,1934), em que a estrutura da palavra poderia ser uma representação icônica espaço-temporal de um evento, ou seja, a forma como o discurso é organizado, em parte, por objetivos comunicativos. Integram o grupo de princípios universais a gramaticalização, informatividade, transitividade e plano discursivo, marcação e iconicidade (CUNHA, 2013). 
Contudo, vamos defender aqui que, na aquisição de linguagem, o que transparece acontecer é um mecanismo default de acatamento de nomes arbitrários, sobre os quais as crianças não têm consciência. Acreditamos que elas têm noção da possibilidade de lançarem mão da iconicidade para os casos de criação de novos nomes, mas não têm consciência de que passivamente acatam os nomes já estabelecidos que lhes são indicados pela comunidade de fala, mesmo quando do nome nada emana em relação ao objeto. A iconicidade seria, assim, um recurso mais geral e mais saliente para as crianças porque envolve procurar correspondências para nomear. Enquanto a ação cerebral de mera associação de um significante já estabelecido a um significado é tão automática, inconsciente e forte que a pessoa é levada a pensar que haveria seu agenciamento, quando na verdade há uma total arbitrariedade e acatamento passivo do nome já estabelecido pela comunidade de fala. Aceita-se que carro é carro sem haver nenhuma razão para isto.

O presente trabalho se propõe a examinar a iconicidade manifestada através do realismo nominal. Para tal, propomos um exame entre diferentes faixas etárias (4 a 6 anos), a fim de: (i) capturar o momento de utilização do recurso cognitivo da iconicidade; (ii) identificar nas faixas etárias um possível desgaste para esse efeito e (iii) discutir a importância de um método de alfabetização que permita ao educador lidar com fenômenos como o realismo nominal.

\section{O experimento}

O teste empregado manipulou o tamanho de objetos e o tamanho de palavras, tendo como meta testar se, as crianças na fase anterior à alfabetização, elaboram a hipótese icônica de que um objeto tido como grande ou pequeno seria representado por uma palavra grande ou pequena, respectivamente.

\subsection{Materiais e Métodos}

\subsubsection{Vídeo Motivacional}

O teste foi precedido por um vídeo motivacional de 3 minutos, cujas cenas principais estão na Figura 2. O vídeo foi montado no Estúdio Camelo Azul (https://www.estudiocameloazul.com/) em Botafogo, na cidade do Rio de Janeiro (RJ). O objetivo do vídeo era engajar o participante na tarefa do experimento.

$\mathrm{Na}$ abertura do vídeo, o personagem, o escritor, interpretado por um ator mirim, está de costas para a câmera enquanto está tendo um ataque de fúria, jogando papéis amassados para o alto (cena 1). Em seguida, virando-se para frente da câmera para falar diretamente com o participante, ele se apresenta como o escritor e conta ter sido o autor de muitas histórias infantis (cena 2) de princesas (cena 3), de bruxas, dragões, torres (cena 4) e de cavaleiros (cena 5). Porém, ele estava atormentado por não conseguir mais escrever suas histórias. Ele relata que ultimamente experienciava uma situação em que as palavras simplesmente sumiam (cenas 6 e 7). O escritor relata que, no passado, quando por acaso faltava 
alguma palavra na sua cabeça, ele recorria ao dicionário que sempre tinha boas palavras para dar a ele. Agora, porém, o dicionário também tinha ficado vazio. Ele sacode o livro e mostra que as palavras não estão mais lá (cena 8). Nesse ponto, ele parece ter uma ideia. Pergunta se o participante "topa" ajudá-lo a recuperar as palavras perdidas de seu livro mágico (cena 9). Ele informa que o participante deve achar as palavras e botar dentro do livro dele (o objeto "livro" que ele empunha, funciona como um cofre). Então, o escritor faz o movimento de mandar o dicionário na direção do participante (cenas 10 e 11). Abre-se um portal mágico (efeito de desenho animado) para transportar o dicionário para sala de teste, e o dicionário passa por esse portal (cenas 12, 13 e 14). Na última cena, o escritor em close-up reafirma que conta com o participante para encher o dicionário dele de boas palavras (15). Fim do vídeo.

Figura 2: Cenas do filme motivacional de 3 minutos, que o participante via antes de começar o teste.

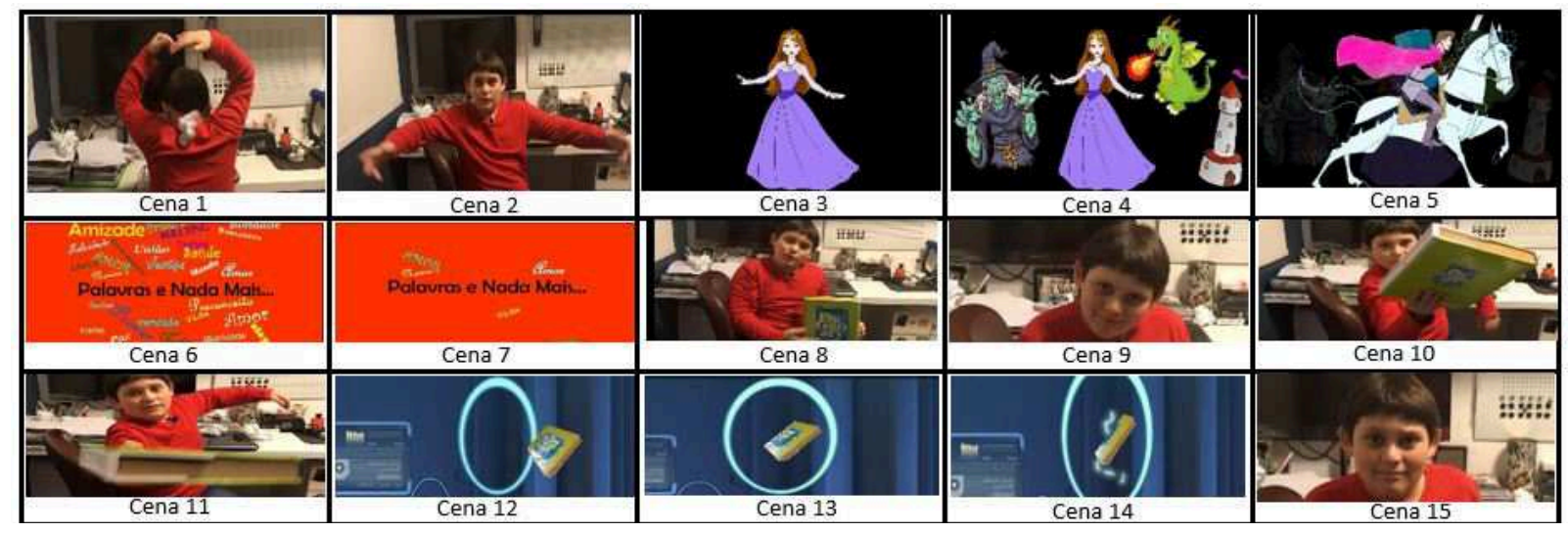

\subsubsection{A tarefa do teste}

Ao término do vídeo, a experimentadora mostrava ao participante uma caixa amarela que estava fechada na mesa do teste (Figura 3). Quando ela abria a caixa, o participante podia ver que o dicionário do escritor estava lá dentro. A experimentadora dizia então ao participante que agora era só ele escolher as palavras certas para encher o dicionário do escritor.

Após essa convocação, o teste começava efetivamente. A experimentadora explicava que o participante iria ver uma figura na tela do computador e que, em seguida, no quadro prateado que estava em frente a ele (Figura 3), ele veria duas palavras presas por velcro. A tarefa do participante seria puxar do quadro prateado a palavra escrita que ele achava que correspondia à figura vista no monitor. Depois de puxar, ele deveria colocar a palavra na caixa amarela. O tempo de reação do participante era marcado pelo momento em que ele começava a puxar a palavra do quadro. Esse tempo era computado através do aperto de botão comandado pela pesquisadora. 
Figura 3: Sala de teste, a caixa amarela,uma experimentadora, um participante e uma assistente.

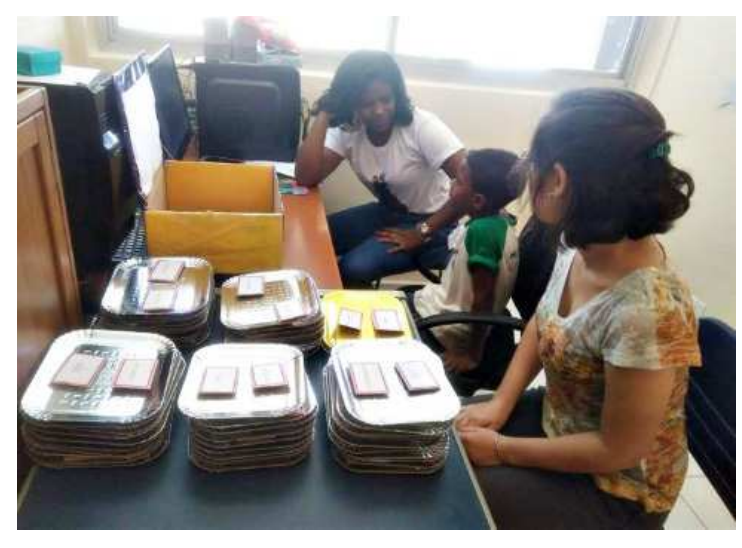

Tanto a apresentação da figura, quanto a computação do tempo de reação foram controlados pelo software e-prime2 da PST (https://pstnet.com/products/e-prime/). Desenhamos a tarefa do participante de forma que envolvesse uma ação motora - puxar o cartão preso a um quadro por velcro e guardar o mesmo na caixa - e não uma que iniciasse uma ação virtual, como o aperto de um botão no computador. Fizemos essa escolha porque a idade dos participantes pedia ações com um nível de materialidade mais explícita para manter os recursos de função executiva ${ }^{3}$ bem ativados (PINTO; FRANÇA, 2018; RODRIGUES, 2011). De fato, com essa rotina semelhante a um jogo do tipo role playing, a taxa de desengajamento da tarefa foi desprezível, totalizando menos de $10 \%$ nos itens computados.

Em contrapartida, esse investimento na ecologia do experimento acabou redundando no fato de que o tempo de reação teve que ser registrado de forma indireta, através da observação da assistente do experimento. A cronologia do teste está na Figura 4.

Figura 4: A cronologia do experimento

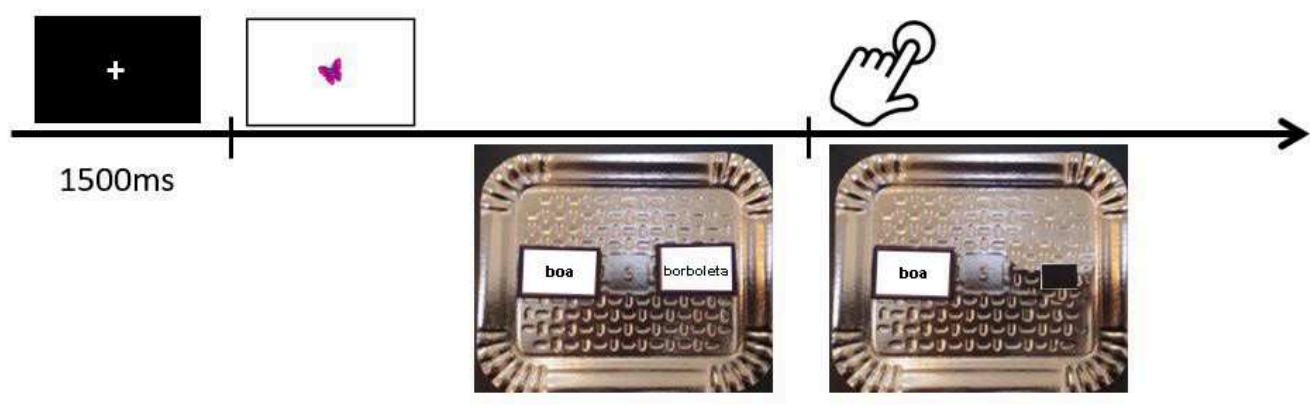

A tarefa do experimento aplicado foi baseada na técnica de Word/Picture Matching, que no nosso caso consistiu numa correspondência entre palavra escrita e imagem. Nossa previsão foi a de que, no teste de pareamento figura/pa- 
lavra escrita, as opções relativas às distratoras demandariam mais tempo já que, por terem o mesmo tamanho, não ofereciam uma motivação icônica, independentemente de serem opções certas ou erradas.

\subsubsection{Estímulos}

$\mathrm{Na}$ tela do computador, aparecia um retângulo (Figura 5). Dentro dele havia uma imagem de um objeto de tamanho grande, médio ou pequeno (Figura 6). Foram utilizadas 48 imagens, sendo 24 imagens-estímulos e 24 imagens-distratoras. As imagens-estímulos eram sempre grandes ou pequenas. As imagens distratoras eram sempre médias.

Figura 5: Tela do experimento contendo um retângulo que delimitava o tamanho das figuras projetadas pelo software de apresentação de estímulos e-prime2.

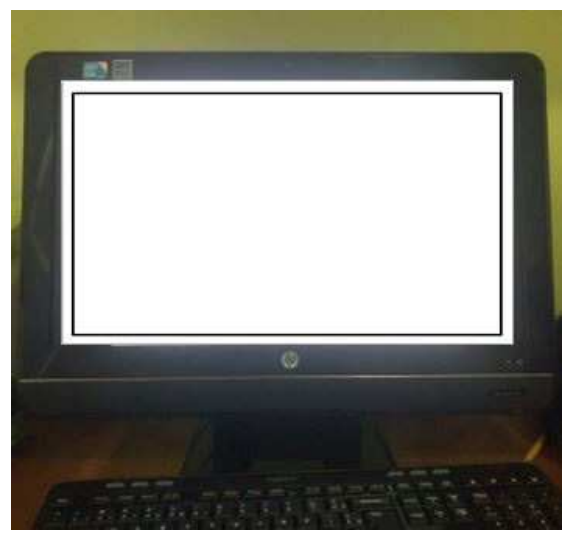

As imagens utilizadas saíram de um banco de desenhos de acesso livre de direitos autorais. São objetos coloridos, de linhas simples, característicos do universo infantil, com traços e coloração seguindo um mesmo padrão feito para crianças.

As proporções grande e pequeno foram estabelecidas por nós, a partir de dois pontos de vista: um da vida real e outro estabelecido pelo enquadre na tela do computador. Em relação à dimensão da vida real, consideramos grande, o objeto cujo tamanho era bem maior do que o tamanho da própria criança. Pequeno era o objeto com tamanho bem menor do que o tamanho da própria criança. Os objetos médios tinham tamanho compatível com o da criança ou poderiam ser empunhados ou levantados por ela.

Em relação ao ponto de vista do enquadre das figuras, usamos como referência um retângulo, dentro do qual apareciam as figuras (Figura 5). As imagens consideradas grandes se expandiam até o limite do retângulo, enquanto as pequenas ocupavam uma região mínima no centro do perímetrodo retângulo (Figura 6).

Figura 6: Exemplos de estímulos experimentais. À esquerda, uma figura representando uma coisa do tamanho grande, hipopótamo, ocupando toda a dimensão do retângulo; no centro uma figura representando alguma coisa de tamanho médio, boneca, ocupando cerca de $40 \%$ do retângulo; à direita uma figura 
representando alguma coisa do tamanho pequeno, borboleta, ocupando só $20 \%$ no centro do retângulo.
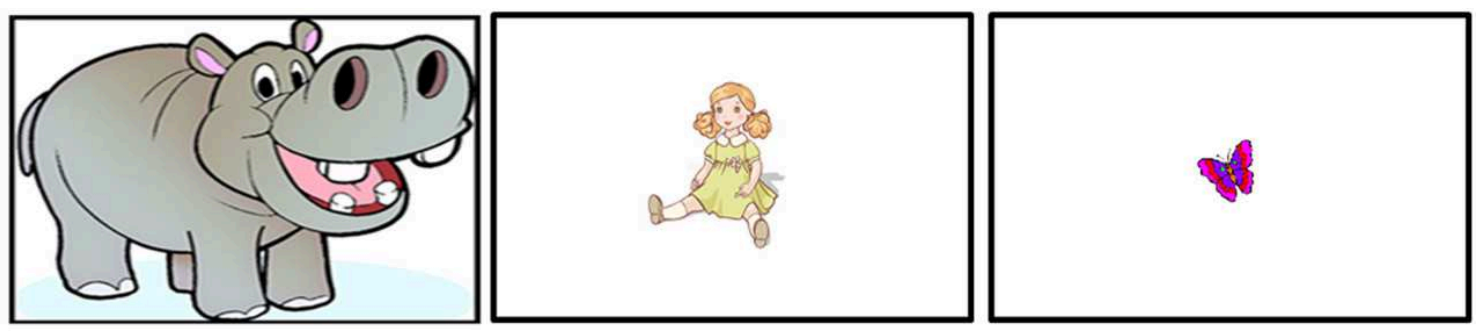

Depois de o participante ver a figura, ele deveria puxar uma dentre as duas palavras presas com um velcro a um quadro de papelão colocado a sua frente. A disposição das palavras seguia uma de quatro possibilidades, variando pseudo -aleatoriamentea cada dupla de palavras apresentada (Figura 7). Essa manipulação visava evitar que houvesse um outro viés icônico de escolha, relativo, por exemplo à precedência por localização espacial do cartão com a palavra.

Figura 7: Exemplos das quatro configurações (a, b, c e d) em que as palavras poderiam ocorrer.
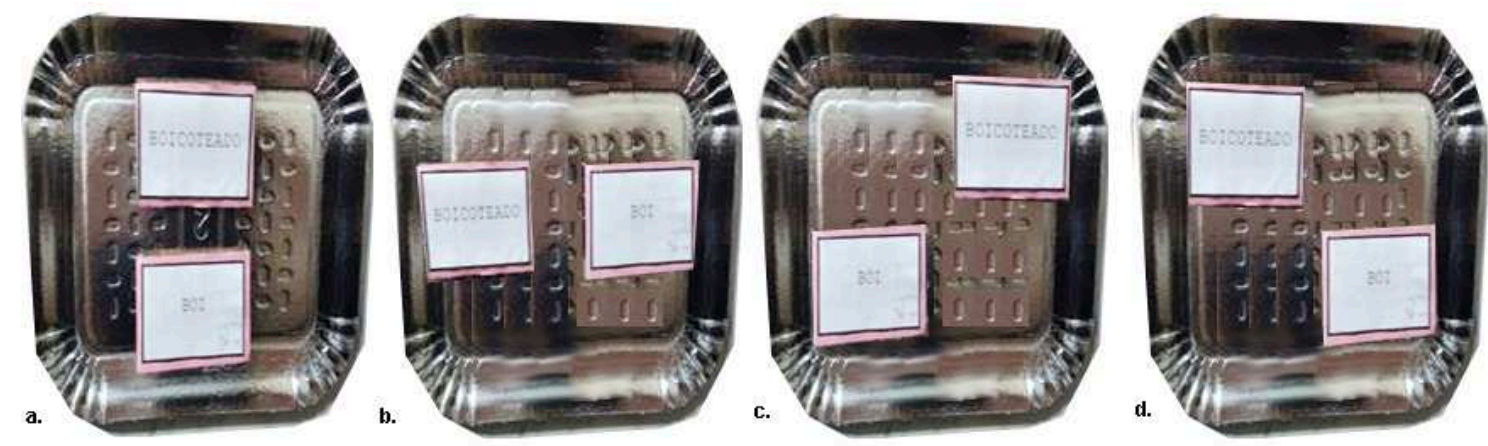

O grupo das palavras-estímulo foi composto por nomes pequenos (de uma e duas sílabas) ou grandes (de quatro ou mais sílabas), como constam na tabela 1. Desse modo, o participante teve acesso a palavras de diferentes quantidades silábicas. Foram utilizadas 24 palavras-estímulo. Também foram incluídos 24 pares de palavras-distratoras, formadas por três sílabas, exatamente.

Tabela 1: Exemplos de palavras de cada tamanho utilizadas no experimento

\begin{tabular}{|l|l|l|}
\hline Palavras Experimentais & Palavras Distratoras \\
\hline Palavras Pequenas & Palavras Grandes & Palavras Médias \\
\hline Sol & joaninha & boneca \\
\hline Boi & dinossauro & caneca \\
\hline Cama & lagartixa & martelo \\
\hline
\end{tabular}

O experimento foi realizado no Laboratório ACESIN 4 /UFRJ. A Plataforma E-prime 2 para Windows foi utilizada para a exibição e coleta dos dados. 


\subsubsection{Participantes}

O teste foi aplicado a um grupo de 16 crianças (seis meninos) do Centro Cultural de Educação Infantil Paulo Freire em Mesquista, Baixada Fluminense, nas três faixas etárias de 4 anos (média 4,5); 5 anos (média 5,7) e 6 anos (média 6,4). Todos os participantes fizeram o teste voluntariamente e seus responsáveis legais assinaram o Termo de Consentimento Livre e Esclarecido. Os participantes realizaram o teste em um PC, com tela de 17 polegadas.

\subsubsection{Desenho experimental}

As variáveis independentes do teste foram: (i) o tamanho da palavra, em dois níveis: palavra grande e palavra pequena; e (ii) o tamanho do objeto, também com dois níveis: objeto grande e objeto pequeno. As variáveis dependentes foram o índice de acurácia dos participantes e tempo médio de resposta na escolha da palavra.

O desenho fatorial do experimento foi definido a partir do número de variáveis independentes e do número de níveis apresentados por elas. Considerando que ambas as variáveis independentes apresentam dois níveis, o cruzamento entre elas produz um design fatorial $2 \times 2$, perfazendo 4 condições, como mostra a tabela 2 :

Tabela 2: Condições obtidas a partir do cruzamento das variáveis independentes. As células com fundo cinza estabelecem uma iconicidade entre o tamanho da palavra e o tamanho da coisa que elas representam

\begin{tabular}{|l|l|l|}
\hline Cruzamento das variáveis & Objeto Grande & Objeto Pequeno \\
\hline Palavra Grande & PGOG & PGOP \\
\hline Palavra Pequena & PPOG & PPOP \\
\hline
\end{tabular}

Os estímulos utilizados no teste foram organizados de forma que todos os participantes tiveram acesso a todos os itens experimentais, mas não os mesmos itens, seguindo uma distribuição entre sujeitos - Within Subject.

\subsubsection{Resultados}

Quando tratamos os resultados no pacote EZAnova através de uma análise de variância bifatorial intrassujeito (aNOVa: Design 2 Within Subject Factors), obtivemos um efeito principal altamente significativo do fator idade: $\mathrm{F}(2,282)$ $=145, \mathrm{p}=0,000001$. Isto é, há comportamento diferente por idade em relação às condições testadas. Também houve efeito principal do fator tipo de parâmetro visual utilizado pelos participantes, ou seja, a utilização de um viés icônico ou não: $\mathrm{F}(1,141)=30,6 \mathrm{p}=0,000001$. Finalmente, houve também efeito de interação entre idade e viés visual: $\mathrm{F}(2,282)=27,5 \mathrm{p}=0,000001$.

Começaremos, agora, a análise detalhada pelos distratores (Figura 8), que nesse teste também foram usados como controle. 
Figura 8: "martelo", utilizada como distrator e controle.

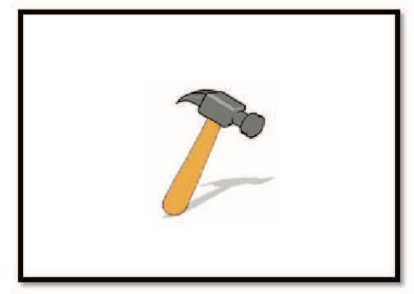

A Figura 8 nos mostra um exemplo de uma figura de distrator utilizado no teste. Após sua exibição, o participante escolhia uma das palavras da bandeja (Figura 9), "MARTELO" e "MARCELO" como opções de resposta na tarefa de escolha. Nessa condição distratora as palavras tinham o mesmo número de grafemas para inibir a escolha pelo viés do realismo nominal:

Figura 9: Quadro com as palavras "marcelo" e "martelo" presos por velcro. O participante deveria escolher uma das opções, puxando o cartão do quadro.

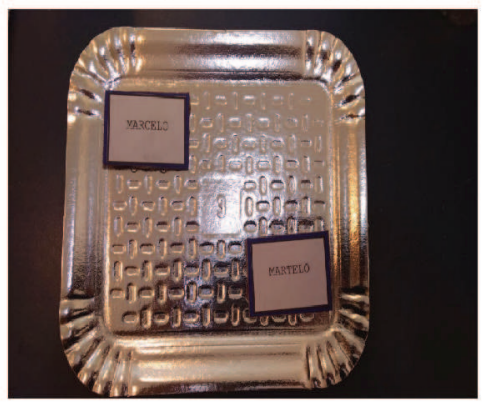

A contagem das escolhas das palavras e também a computação dos acertos por faixa etária estão no Gráfico 1 abaixo:

Gráfico 1: Escolhas das palavras distratoras, plotadas por localização à direita ou à esquerda, opções em que o viés iconicidade foi eliminado: as duas opções tinham o mesmo tamanho.

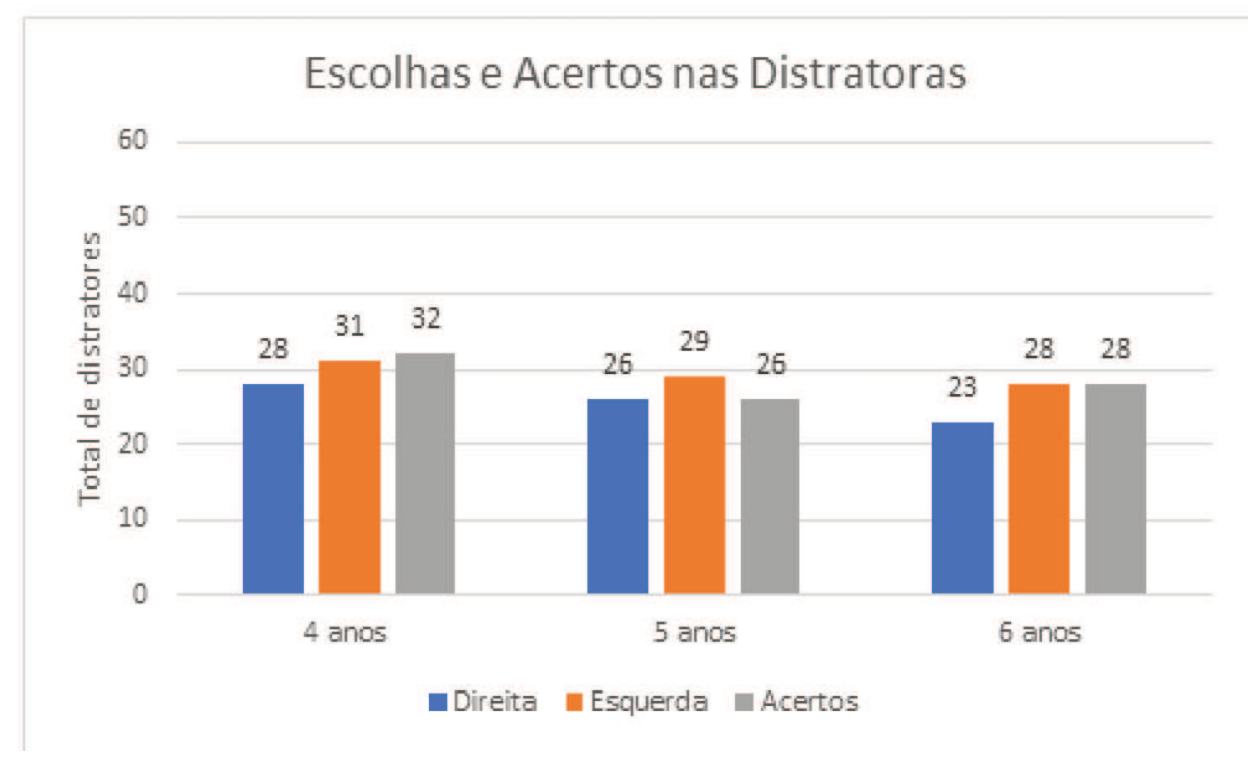


No Gráfico 1, para todas as idades, as escolhas estão muito próximas de 50\% ou 30 itens, ou seja, estão no nível da chance. Isso significa que os participantes, provavelmente, tentaram adivinhar as respostas. Como,nos distratores, o viés tamanho foi neutralizado, tanto no desenho quanto no tamanho das palavras, a aplicação da estratégia de iconicidade não foi implementada e o chute teria sido a única alternativa. Não houve diferença estatística entre as opções, embora haja uma leve tendência para que a palavra da esquerda seja um pouco mais escolhida, talvez em conformidade com o padrão de leitura de português, que já tenha sido percebido por elas como indo da esquerda para a direita. Em termos de acertos, temos mais uma vez um resultado muito perto do nível da chance, mostrando que não houve leitura dos itens.

Já em relação aos resultados da tarefa de escolha envolvendo os itens experimentais, podemos observar no Gráfico 2, abaixo, as escolhas das palavras relacionadas às imagens. Ele é organizado de forma que temos a percentagem de acerto em cada uma das condições:

Gráfico 2: Escolha com viés icônico nos itens experimentais.

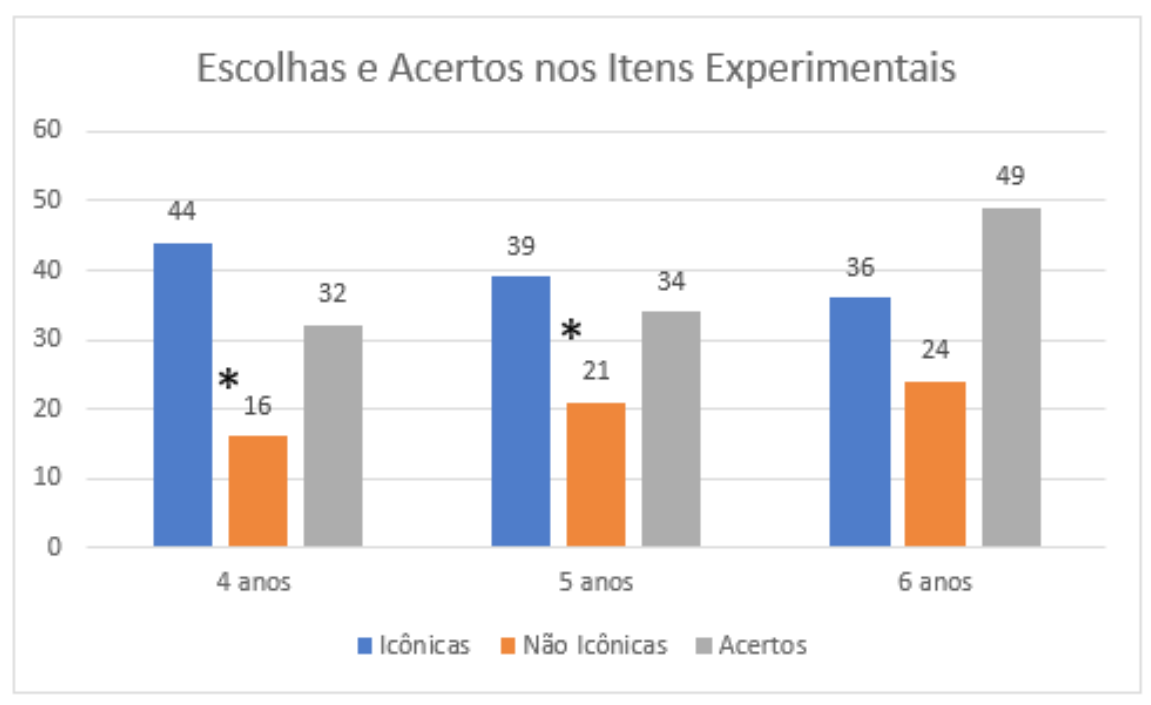

Podemos observar que nas três faixas etárias as escolhas com o viés de iconicidade foram as mais frequentes. O maior índice de escolhas icônicas foi registrado entre os participantes de 4 anos, com 44 escolhas icônicas versus 16 não icônicas equivalendo a 73\%. Essa foi uma comparação com significância estatística. $(\mathrm{t}(141)=4,65 \mathrm{p}=0,0001)$. Depois, vieram os participantes de 5 anos, com 39 escolhas icônicas e 21 não icônicas, equivalendo a 65\%. Essa comparação também resultou em significância estatística $(t(141)=4,12 \mathrm{p}=0,0001)$. Por fim, os participantes de 6 anos, com 36 escolhas equivalendo a 55\%. Essa última comparação entre escolhas icônicas e não icônicas para os participantes de 6 anos resultou apenas em tendência estatística $(t(141)=1,90 \mathrm{p}=0,0590)$.

No cômputo geral, nossos resultados indicam que os participantes foram influenciados pela iconicidade. Também pode ser verificado que as diferenças percentuais entre as condições icônicas e não-icônicas parecem diminuir ao 
longo das idades, mostrando que a opção pela iconicidade decresce nas faixas etárias mais altas.

Quanto aos acertos, o maior índice de escolhas corretas foi registrado nos participantes de 6 anos ( 49 respostas corretas equivalendo a $81 \%$ ), seguidos pelos participantes de 5 anos (34 respostas corretas equivalendo a 56\%) e por fim os participantes de 4 anos (32 escolhas equivalendo a 53\%). Tanto os participantes de 4 , quanto os de 5 anos tiveram acertos no nível da chance, quer dizer, se comportaram nos itens experimentais como se comportaram com os distratores, mostrando que não estão dominando as correspondências reais da leitura.

O fato de os participantes de 6 anos não terem tido acertos acima da média nas palavras distratoras demonstra que as correspondências grafema-fonema ainda não estão sendo levadas em consideração por eles e que eles não estão realmente lendo. Mas, pelo alto índice de acertos, esses participantes de 6 anos demonstraram que estão contando as sílabas, mesmo que tentativamente, e que foi a diferença de tamanho entre as palavras escritas que serviu de guia para a resposta correta nas condições experimentais. Talvez eles já façam algum nível de correspondências entre o número de articulações e os grafemas que eles vêem na palavra escrita. Embora não tenham ouvido a pronúncia das palavras, podem ter se guiado por articulação implícita e acertaram porque contaram as sílabas.

De fato, presenciamos alguns participantes, aliás nas três faixas etárias, pronunciando as palavras silenciosamente, guiando-se pelo desenho, mas esse fator não foi controlado.

Faremos adiante uma verificação qualitativa, observando, participante a participante, dentro de cada faixa etária, para verificarmos o peso da escolha individual dentro de cada grupo. Alguns participantes já podem ter substituído o realismo nominal por outra forma de iconicidade. $O$ resultado desse controle está no Gráfico 3.

Gráfico 3: Escolhas icônicas por participante, por idade nos itens experimentais.

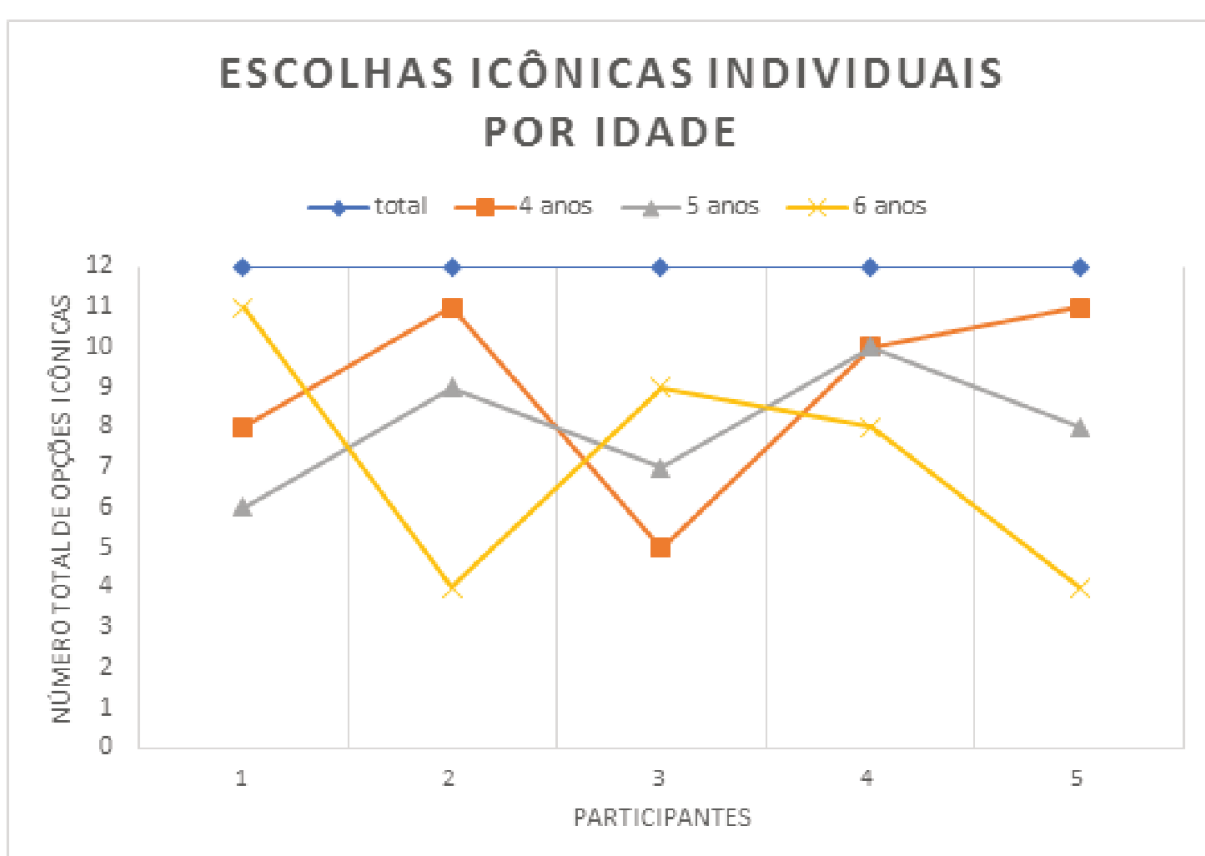


No grupo de 4 anos, quatro dos cinco participantes fizeram escolhas francamente icônicas. No grupo de 5 e no de 6 anos foram três participantes. Qualitativamente falando, dois dos participantes de 4 anos e um de 6 anos guiaram-se completamente pela estratégia icônica. Assim, esse participante com estratégia de correspondência icônica aos 6 anos estará iniciando na classe de alfabetização com essas expectativas icônicas de relação entre palavra e referente.

No Gráfico 4, a seguir, apresentamos o tempo de resposta de acordo com as condições do experimento medido em milissegundos:

Gráfico 4: Iconicidade como viés de tempo de resposta por idade.

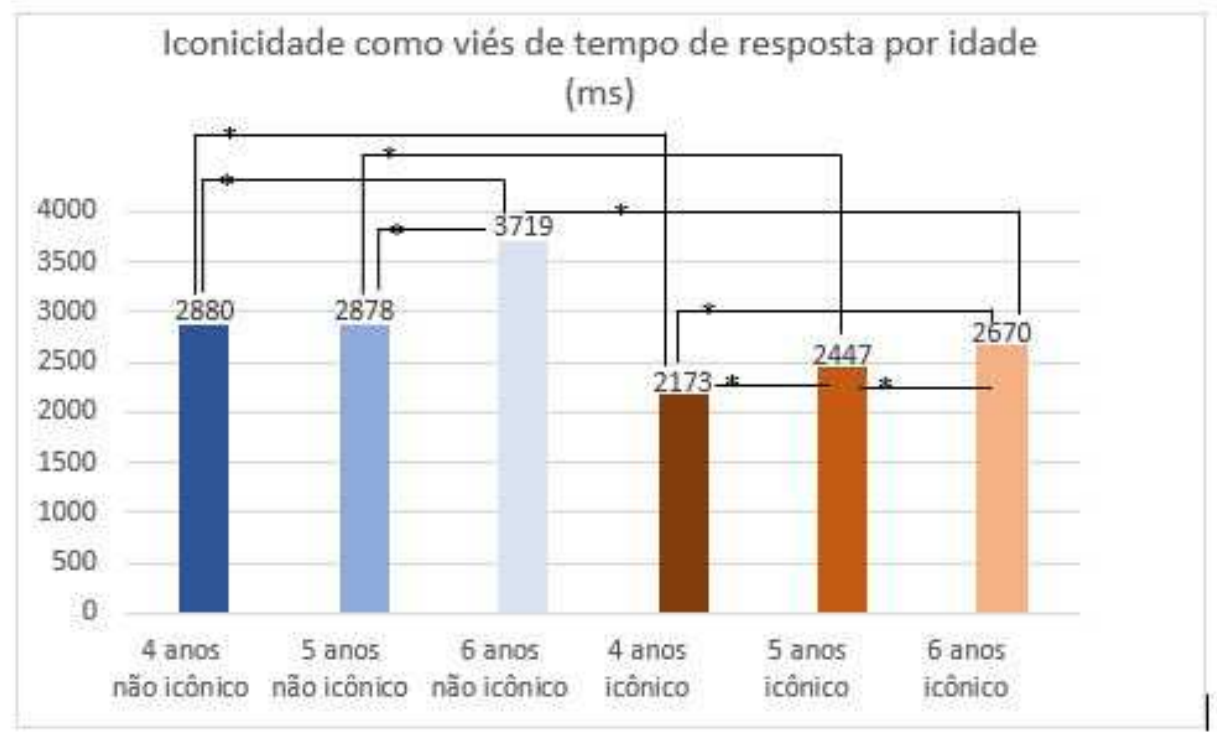

Como podemos ver no Gráfico 3, nas três idades ( 3 , 4, e 5 anos), a escolha seguindo o viés de iconicidade (três últimas colunas) - ou seja, uma palavra com muitos grafemas sendo escolhida como a palavra escrita para um objeto grande, ou uma palavra com poucos grafemas sendo escolhida como a palavra escrita para um objeto pequeno - demandou menos tempo do que as palavras sem esse viés nas três idades, o que corrobora os dados presentes no Gráfico 2, que mostra o viés icônico atuando fortemente nos participantes estudados. Essa correspondência é mais imediata e explica a maior rapidez de escolha com essa motivação.

Em relação ao tipo de viés de cada grupo, encontramos diferenças entre praticamente todos os grupos quando comparamos icônico e não icônico.

Em relação às faixas etárias dos participantes, podemos observar diferenças significativas entre o grupo dos mais novos, 4 anos, e o grupo dos mais velhos, 6 anos, tanto nas condições icônicas quando nas não-icônicas ([4_Icônico]vs[6_Icônico] $\mathrm{t}(141)=13,80$ p= 0,0001) e [4_não-Icônico]vs[6_não-Icônico] $\mathrm{t}(141)=15,46 \mathrm{p}<0,0001$. O grupo de 4 anos resolve a tarefa mais rapidamente nas relações icônicas do que o grupo de crianças de 6 anos. Isso quer dizer que as correspondências por tamanho são rápidas. Na faixa etária dos 6 anos, talvez os participantes não estejam aplicando realismo nominal, mas sim outro pareamento icônico, do tipo localização da palavra no quadro, ou ainda contagem de sílabas 
através de articulação implícita. Essas são estratégias que demorariam um pouco mais do que as guiadas pelo realismo nominal e poderiam explicar o maior tempo de reação dessa faixa etária.

De acordo com esses resultados, podemos pensar que o grupo de 6 anos ainda não lê, mas parece não usar tanto a iconicidade como um recurso para descobrir a palavra certa quanto o grupo de 4 anos e, por isso, a diferença de latência temporal entre os grupos de 4 e 6 anos. Esses resultados também seguem os encontrados no gráfico 2 em relação ao fator Idade, já que quanto maior a idade do grupo, a iconicidade do realismo nominal parece atuar menos na escolha da palavra.

\section{Discussão}

Desenvolvemos um teste no estilo role-playing para engajar as crianças na tarefa do experimento, que era a escolha da palavra que nomeava as imagens mostradas. O teste foi bem-sucedido e envolveu as crianças no objetivo do jogo. De uma forma geral, de acordo com nossos resultados, os participantes tenderam a fazer suas escolhas levados pelo viés icônico; isto é, procuram fazer uma correspondência entre o tamanho do objeto e o tamanho da palavra escrita, uma aposta conhecida como Realismo Nominal (PIAGET, 1962). Essa tendência foi mais forte com os participantes mais novos, mas também pode ser encontrada em menor proporção nos mais velhos.

Isso nos permite propor que, antes do processo formal de aquisição da leitura, a relação de iconicidade entre o tamanho da palavra e o tamanho do objeto se mostra como um recurso provisório explorado por muitas crianças não alfabetizadas, mas que, com o tempo, deixa de ser um recurso principal no pareamento forma-conteúdo. Essa estratégia icônica parece ser fruto da influência de dois módulos cognitivos, um sobre o outro: o da linguagem e o da visão.

Dessa forma, como a visão influencia muito a linguagem, inicialmente, a interpretação visual da proporção do tamanho das coisas e das palavras levou as crianças a fazerem opções icônicas no momento de relacionar a forma escrita aos objetos. Nossa previsão é a de que, eventualmente, na escola, a aposta icônica poderá ser abandonada por essas crianças e novos padrões surgirão, como a preciosa relação entre grafema e fonema, que pode realmente tomar lugar para o aprofundamento da capacidade leitora.

Porém, nossos resultados indicam que, embora a hipótese icônica do realismo nominal sofra desgaste natural nas faixas etárias no período pré-alfabetização, e tenda a desaparecer, pelo menos 1 dos 5 participantes testados de seis anos mostrou ter preservado uma forma de aposta nessa hipótese. Para esse participante, o viés icônico operou em 11 das 12 possibilidades icônicas de seleção. Isso significa que esse participante vai começar o período de instrução formal na classe de alfabetização fazendo uma aposta forte no realismo nominal.

Se a proporção do nosso experimento se mantiver nas classes de alfabetização, em uma turma média de 25 crianças, 5 apostarão que o sistema de escrita se baseia em iconicidade. Isso nos leva a pensar sobre que tipo de educação alfabe- 
tizadora seria adequada para ajudar essas crianças a trocarem a aposta falsa de relacionamento entre o tamanho da palavra escrita e seu significado pela relação grafema-fonema.

Sem pensarmos em uma classificação muito restritiva que, certamente, poderia, com bom propósito, ser apresentada pela área da educação, para fins de encaminhamento desses achados experimentais, gostaríamos de classificar grosseiramente os métodos de alfabetização em dois grandes tipos: os globais e os fônicos.

No Brasil, diferentes versões dos métodos globais vêm sendo adotadas metodologicamente desde 1907. Arnaldo Barreto foi o autor da primeira Cartela Analytica, instrumento globalista que foi amplamente disseminado por todo o país (SCLIAR-CABRAL, 2013). Estes métodos priorizam a compreensão holística contexto-situacional. A aquisição da leitura e da escrita se dá pela identificação visual de toda palavra mantida pelo sincretismo característico do pensamento infantil, que se ancora na visão para a resolução de problemas de outras ordens. Primeiro, percebe-se o todo para, depois, se observarem as partes. Os globalistas acreditam que o conhecimento da relação grafema/fonema, que é efetivamente usado no sistema de escrita, será eventualmente adquirido pela criança de forma natural e espontânea somente após o reconhecimento total da maioria das palavras já ter sido estabelecido. Isto é, o método global acredita que existem estágios na alfabetização e que o primeiro deles deva ser bastante icônico e top-down: o desenho das letras que se veem nas embalagens dos produtos poderá ser reconhecido nos textos a partir de uma logografia generalizada. Em um segundo estágio, a familiaridade com os símbolos da escrita culminará, a partir de uma sistematização que, finalmente, poderá indicar domínio das relações grafema-fonema.

Já os métodos fônicos, que começaram a ser mais usados no Brasil a partir dos anos 1980, se baseiam na explicitação e instrução do princípio alfabético, nas correspondências grafema-fonema e explicitação de outras correspondências grafofonológicas. O maior desafio do método fônico é o desenvolvimento da consciência fonêmica, que torna a criança um leitor independente que pode ler qualquer coisa escrita, com boa compreensão (MORAIS, 2013).

Considerando que o uso da iconicidade é mantido por muitas crianças como recurso provisório para o estabelecimento das relações entre palavra e referentes,os métodos globais de alfabetização parecem não ser os mais apropriados, uma vez que, ao reconhecer a palavra de forma holística, as crianças têm mais um incentivo para terem suas crenças no realismo nominal reforçadas. Instituir como método uma correspondência entre a mancha da palavra e seu significado, numa relação relâmpago pautada pela memorização do contorno, logografia ou mesmo até pela observação só do início da palavra se constitui, assim, em um desserviço a esse público, fadado a seguir por anos na educação básica sem entender os processos de correspondências do sistema de escrita.

Para abandonar a hipótese icônica, a criança precisa ser diretamente orientada a explorar o interior das palavras, decodificando suas unidades, estabelecendo as relações grafema-fonema e, enfim, acessando os seus significados fora e dentro do contexto linguístico. 


\section{Agradecimentos}

Nossos penhorados agradecimentos e nosso respeito aos alunos, professores, inspetores, merendeiras e, em especial, à coordenadora do Centro Cultural de Educação Infantil Paulo Freire, Professora Heloísa de Araújo Santos de Brito, em Mesquista (RJ), Baixada Fluminense, por aceitarem estabelecer uma parceria entre a UFRJ e a creche através do nosso laboratório. Agradecemos também a Sammy Cardoso, por proporcionar a nossa aproximação com essa creche tão bem organizada e valorosa.

Agradecemos ao ator mirim Bernardo Riley pela interpretação do personagem do Escritor e à Professora Aleria Lage pela dublagem dos personagens do desenho animado.

Agradecemos à Fundação Carlos Chagas Filho de Amparo à Pesquisa do Estado do Rio de Janeiro - FAPERJ, pelas bolsas Nota 10 de Mestrado e Cientistas do Nosso Estado dirigidas respectivamente à primeira e à terceira autoras.

Agradecemos à CAPES pela bolsa de Doutoramento e pela Bolsa de PDSE dirigidas à segunda autora. Agradecemos também ao CNPq pela Bolsa de Produtividade de Pesquisa mantida pela terceira autora.

\section{Notas}

1. Nesse Diálogo Platônico, Sócrates é questionado por Crátilo e Hermógenes, sobre se os nomes das coisas foram determinados por uma convenção ou se são emanações naturais da coisa representada. Isto é, se a linguagem é um sistema de símbolos arbitrários ou se as palavras possuem uma relação intrínseca com as coisas que elas significam.

2. Esse filme muito ilustrativo dessa fase de desenvolvimento infantil está disponível no endereço https://www.youtube.com/watch?v=e2EFMWwITLA

3. Funções Executivas (FEs): um grupo de habilidades mentais que nos permitem identificar problemas, estabelecer metas e planos de ação em direção às soluções.

4. ACESIN é o Laboratório de Acesso Sintático do Programa de Pós Graduação em Linguística da UFRJ (http://www.acesin.letras.ufrj.br/ ). Este estudo é parte de uma série de estudos sobre o recrutamento de alguma forma de iconicidade como estratégia cognitiva provisória anterior à alfabetização.

\section{Referências}

ANDERSON, John Robert. The Architecture of Complexity. Cambridge MA: Harvard Univ. Press. 1983.

ANDRADE, Isadora Rodrigues; FRANÇA, Aniela Improta; SAMPAIO, Thiago Oliveira Mota. Dinâmicas da interação nature-nurture: do imprinting à reciclagem neuronal. ReVel, vol. 16, n. 31. 2018.

BUHLER, Karl. The Theory of Language: The Representational Function of Language (Sprachtheorie). Trad. Donald Fraser Goodwin. Amsterdam: John Benjamins Publishing Company. 1990, p. 508.

CARRAHER, Terezinha Nunes \& REGO, Lúcia Lins Browne. O realismo nominal como obstáculo na aprendizagem da leitura. Cadernos de Pesquisa, 39. p. 3-10.1981. CARRUTHERS, Peter; LAURENCE, Stephen \& STICH, Stephen. The Innate Mind: Structure and Contents. New York: Oxford University Press New York. 2005. 
CHURCHLAND, Paul. Montgomery. A Neurocomputational Perspective: The Nature of Mind and the Structure of Science. Cambridge, Massachusetts: MIT Press. 1989.

COHEN, Laurent. \& DEHAENE, Stanislas. Specialization within the ventral stream: the case for the visual word form area. Neuroimage, 22(1), p. 466-476. 2004.

CROFT, William. Typology and Universals. ${ }^{\text {ed. }}$ Cambridge: Cambridge University Press. 2003, p. 368.

CUNHA, Angélica F. da. Funcionalismo. In: MARTELOTTA, Mário E. Manual de Linguística. São Paulo: Contexto. 2a ed. 2013, p. 157 - 174.

DAVIS, Katie; CHRISTODOULOU, Joanna; SEIDER, Scott; GARDNER, Howard. The Theory of Multiple Intelligences. In: STERNBERG, R. J. \& KAUFMAN, S.B. (eds). The Cambridge Handbook of Intelligence. Cambridge University Press. 2011.

DEHAENE, Stanislas. \& COHEN, Laurent. Cultural recycling of cortical maps. Neuron, 56(2). p. 384-98. 2007.

DEHAENE, Stanislas. \& COHEN, Laurent. The unique role of the visual word form area in reading. Trends Cogn Sci. p. 254-62, 2011.

DEHAENE, Stanislas. Os Neurônios da Leitura: Como a Ciência Explica a Nossa Capacidade de Ler. Porto Alegre: Penso. 2012.

DEHAENE, Stanislas; PEGADO, Felipe; BRAGA, Lucia W; VENTURA, Pedro, FILHO Gilberto Nune; JOBERT, Antoine; DEHAENE-LAMBERTZ, Gislaine; KOLINSKY, Régine; MORAIS, João; COHEN, Laurent. How learning to read changes the cortical networks for vision and language. Science. v. 330, n. 6009. p. 1359-1364. 2010.

DINGEMANSE, Mark; ROBERTS, Sean G.; BARANOVA, Julija; BLYTHE, Joe; DREW, Paul; FLOYD, Simeon et al. Universal Principles in the Repair of Communication Problems. PLoS ONE 10(9). 2015, p. 1 - 15.

FRANÇA, Aniela Improta; LAGE, Aleria C. Uma visão biolinguística da arbitrariedade saussuriana. Letras de Hoje, Porto Alegre, v. 48, n. 3. 299-308. 2013.

FERREIRO, Emilia, \& TEBEROSKY, Ana. A Psicogênese da Língua Escrita.Porto Alegre, RS: Artes Médicas. 1984.

FETZER, James H. Connectionism and Cognition: Why Fodor and Pylyshyn are Wrong. In: LUTZ, R. and CLARK, A. (eds). Connectionism in Context. Germany: Springer-Verlag. p. 37-56. 1992.

FODOR, Jerry. Alan. The Modularity of Mind. Cambridge (Mass): The MIT Press. 1983.

HAIMAN, John. In defense of iconicity, Cognitive Linguistics 19 (1): 35-48. 2008.

ISHAI, Alumit; UNGERLEIDER, Leslie; MARTIN, Alex; HAXBY, James. The representation of objects in the human occipital and temporal cortex. Journal of Cognitive Neuroscience, 12, Suppl. p. 35-51. 2000.

LAKOFF, George. Women fire and dangerous things: what categories reveal about the mind. Chicago: University of Chicago Press. 1987.

LAKOFF, George. \& JOHNSON, Mark. Metaphors We Live By. Chicago: Chicago University Press. 1980.

LAKOFF, George. \& TURNER, Mark. More than cool reason: a field guide to poetic metaphor. Chicago: The University of Chicago Press, 1989.

LANGACKER, Ronald. Foundations of Cognitive Grammar: Theoretical Prerequisites. Stanford, CA: Stanford University Press, v.1., 1987. 
KÖHLER, Wolfgang. Gestalt Psychology. Nova York: Liveright. 1929.

KUHN, Melanie R.; SCHWANENFLUGEL, Paula. J., MEISINGER, Elizabeth. B. et al. Aligning theory and assessment of reading fluency: Automaticity, prosody, and definitions of fluency. Reading Research Quarterly, 45(2). p. 230-251. 2010.

LENNEBERG, Eric Heinz. Biological Foundations of language. Oxford: Wiley, 489p. 1967.

LOGAN, Gordon D. Automaticity and reading: perspectives from the instance theory of automatization. Reading \& Writing Quarterly, 13: 2. p. 123-146. 1997.

MAIA, Marcus.; LEMLE, Miriam; FRANÇA, Aniela Improta. Efeito Stroop e rastreamento ocular no processamento de palavras. Ciências \& Cognição. v. 4. p. 2-17. 2007.

MALUF, Maria Regina, \& BARRERA, Sylvia Domingos. Consciência fonológica e linguagem escrita em pré-escolares. Psicologia: Reflexão e Crítica, 10(1). p.125145. 1997.

MONTEIRO, U. N. Consciência metalingüística: Uma análise em adultos analfabetos. Dissertação de Mestrado não-publicada, Universidade Federal de Pernambuco, Recife, PE. 1981.

MOORS, Agnes; De HOUWER, Jan. Automaticity: a theoretical and conceptual analysis. Psychological Bulletin, 132(2) p. 297-326. 2006.

MORAIS, José. Criar leitores - Para professores e educadores. Barueri, SP: Manole, 154 p. ISBN: 978-85-7868-077-0. Boletim - Academia Paulista de Psicologia, 36(90), p. 214-217. 2013.

NIEMEYER, Frederick.J. Iconicity and Generative Grammar. Language, vol. 68, n. 4, 1992, p. 756-796.

PERNISS, Pamela et al. Iconicity as a general property of language: evidence from spoken and signed languages. Frontiers in psychology. vol. 1227, 2010, p. 1 - 15.

PIAGET, Jean. A Representação do Mundo na Criança. Rio de Janeiro, RJ: Record, 1962.

PINTO, Mayara.; FRANÇA, Aniela Improta. Preste atenção às Funções Executivas na pesquisa em aquisição de linguagem: o engajamento de participantes infantis depende delas. Revista LinguíStica, vol. 14, 2018, p. 21 - 34.

PUCE, Aina; ALISSON, Truett.; ASGARI, Maryan; GORE, John C.; MCCARTHY, Gregory. Differential Sensitivity of Human Visual Cortex to Faces, Letterstrings, and Textures: A Functional Magnetic Resonance Imaging Study. The Journal of Neuroscience, 16(16). p. 5205-5215.1996.

RAMACHANDRAN, Vilayanur Subramanian; HUBBARD, Edward M. Synaesthesia - A Window into Perception, Thought and Language. Journal of Consciousness Studies, 8, No. 12. p. 3-34. 2001.

RODRIGUES, Erica dos Santos. O papel de mecanismos de controle executivo no processo linguistico: diferença de desempenho entre crianças e adultos em tarefas experimentais. Revista LinguíStica / Revista do Programa de Pós-Graduação em Linguística da Universidade Federal do Rio de Janeiro. Vol. 7, n. 2, dez. 2011.

SAUSSURE, Ferdinand de. Curso de Linguística Geral. Tradução Antônio Chelini, José Paulo Paes, Isidoro Blikstein. 25.ed. São Paulo: Cultrix. 1999.

SCLIAR-CABRAL, Leonor. A desmistificação do método global. Letras de Hoje, Porto Alegre, v. 48, n. 1. p. 6-11. 2013.

STANOVICH, Keith E. Concepts in developmental theories of reading skill: Cognitive resources, automaticity, and modularity. Developmental Review, 10. 72-100. 1990. 
STROOP, John Ridley. Studies of interference in serial verbal reactions. J. Exp. Psychol. 18. p. 643-662. 1935.

WU, Yinghao.; HONIG, Barry. Theory and simulations of adhesion receptor dimerization on membrane surfaces. Biophysical Journal 104 (6), 1221-1229. 2013.

Recebido em: 04/03/2019

Aceito em: 04/07/2019 